\title{
Analysis of Clinicopathological Characteristics and Prognosis of Young Patients with Hepatocellular Carcinoma after Hepatectomy
}

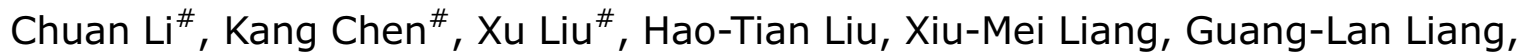 \\ Shao-Tong Tang, Rong-Rui Huo, Liang Ma, Bang-Be Xiang, Jian-Hong Zhong* and Le-Qun Li* \\ Hepatobiliary Surgery Department, Guangxi Liver Cancer Diagnosis and Treatment Engineering and Technology Research Center, \\ Guangxi Medical University Cancer Hospital, Nanning, Guangxi, China
}

\begin{abstract}
Background and Aims: This study was designed to analyze the effects of age and clinicopathological characteristics on prognosis of Chinese patients with hepatocellular carcinoma (HCC). Methods: The clinical data of $2032 \mathrm{HCC}$ patients who were first diagnosed with $\mathrm{HCC}$ and underwent curative hepatectomy in our hospital between January 2006 and January 2011 were retrospectively analyzed. Results: Younger HCC patients (age $<40$ years, $n=465$ ) had a significantly higher hepatitis $B$ infection rate, larger tumors, higher alpha-fetoprotein levels, higher preoperative liver function, and more frequent vascular invasions than older patients. Most younger patients were suitable for anatomical hepatectomy, and their tumors were found to be at a highly advanced stage. The recurrence-free survival and overall survival rates of younger HCC patients were significantly worse than those of older patients but this difference disappeared after propensity score matching. Multivariate analysis of pre-matched samples showed that age $\leq 40$ years was one of the independent risk factors associated with poor overall survival. Conclusions: Younger patients showed different clinicopathological characteristics than older patients, such as higher rates of hepatitis $B$ infection and advanced tumors. The recurrence-free survival and overall survival rates of younger HCC patients after hepatectomy may be similar to those of older patients.

Citation of this article: Li C, Chen K, Liu X, Liu HT, Liang XM, Liang GL, et al. Analysis of clinicopathological characteristics and prognosis of young patients with hepatocellular carcinoma after hepatectomy. J Clin Transl Hepatol 2020;8(3):285291. doi: 10.14218/JCTH.2020.00021.
\end{abstract}

Keywords: Hepatocellular carcinoma; Hepatectomy; Age; Prognosis; Overall survival; Hepatitis B.

Abbreviations: AFP, alpha-fetoprotein; ALB, albumin; ALT, alanine aminotransferase; AST, aspartate aminotransferase; BCLC, Barcelona Clinic Liver Cancer; HBsAg, hepatitis B surface antigen; HCC, hepatocellular carcinoma; OS, overall survival; PA, prealbumin; RFS, recurrence-free survival.

Received: 26 March 2020; Revised: 26 June 2020; Accepted: 17 July 2020

\#These authors contributed equally to this manuscript.

* Correspondence to: Jian-Hong Zhong and Le-Qun Li, Hepatobiliary Surgery Department, Affiliated Tumor Hospital of Guangxi Medical University, He Di Rd \#71, Nanning, Guangxi 530021, China. Tel: +86-771-5330855, Fax: +86-771531-2000, E-mails: zhongjianhong@gxmu.edu.cn or zhongjianhong66@163.com (JHZ), xitongpingjia@163.com (LQL)

\section{Introduction}

Hepatocellular carcinoma (HCC) is one of the most common malignant tumors, causing approximately 782,000 deaths per year. ${ }^{1}$ Hepatectomy is currently the preferred treatment for HCC and can significantly improve the prognosis of HCC patients. ${ }^{2}$ In China, about $33 \%$ of patients received hepatectomy when diagnosed with $\mathrm{HCC}$, but tumor recurrence and metastasis often occur after surgery and prognosis is poor. ${ }^{3}$ There are many factors that affect the prognosis of HCC patients, such as portal vein tumor thrombus, tumor diameter, and Barcelona Clinic Liver Cancer (BCLC) status. ${ }^{4-6}$ However, the effect of age on the prognosis of HCC after hepatectomy remains unclear.

It has been previously reported that age is related to the prognosis of multiple solid tumors. For example, the prognosis of younger patients with papillary thyroid cancer or bladder cancer is better than that of older patients. ${ }^{7,8}$ Conversely, older patients with breast or gastric cancer seem to have a better prognosis than younger patients. ${ }^{9,10}$ For HCC, the literature comparing clinicopathological characteristics and prognosis between younger and older patients is inconsistent, which may reflect the different ethnic groups, disease stages and comorbidities in the samples. Despite differences in outcomes regarding clinicopathological characteristics, in most literature reports, younger patients have higher rates of hepatitis B virus infection, more advanced tumor status, and better liver function than older patients. ${ }^{11,12}$ This prompted our strong interest in whether younger patients have clinicopathological characteristics different from those of older patients.

Therefore, our objective was to investigate the effect of age on the prognosis of HCC after curative hepatectomy. Using 40 years as the cut-off, we stratified patients into younger and older groups and compared their clinicopathological characteristics, prognostic factors, recurrence-free survival (RFS) and overall survival (OS).

\section{Methods}

\section{Patients}

This study was approved by the Ethics Committee of the Guangxi Medical University Cancer Hospital. Clinical data were retrospectively analyzed from $2032 \mathrm{HCC}$ patients admitted to the Guangxi Medical University Cancer Hospital 
between January 2006 and January 2011. All patients underwent curative hepatectomy, and their HCC was pathologically confirmed. The inclusion criteria for this study were: (1) patients who were hospitalized for the first time and underwent curative hepatectomy (macroscopically tumor-free) without preoperative neoadjuvant therapy; (2) postoperative pathology-based diagnosis of HCC; (3) no previous history of primary tumors; and (4) complete clinical and pathological data. Patients were excluded if they had (1) severe cardiopulmonary, renal, or brain dysfunction, or (2) known distant metastatic cancer.

\section{Hepatectomy}

Bilateral subcostal incisions or L-shaped laparotomy incisions with or without upward midline extension were used. During the hepatectomy, the gallbladder was routinely excised, and in order to avoid intraoperative blood loss as much as possible, the Pringle operation was performed intermittently for a time duration of less than 20 m each time with a clampfree interval of $5 \mathrm{~m}^{13-15}$

\section{Data collection}

Baseline data and clinical data were collected for each patient, including age, sex, family history of HCC, presence of hepatitis B surface antigen (HBsAg) and hepatitis C antibody, preoperative alpha-fetoprotein (AFP) levels, Child-Pugh grade, albumin-bilirubin scores, surgical method, postoperative complications, and pathological features of tumors (tumor capsule, size, number, invasion). The following preoperative indicators were also collected and used to assess preoperative liver function: platelet count, prothrombin time, levels of albumin (ALB), prealbumin (PA), alanine aminotransferase (referred to herein as ALT), total bilirubin, aspartate aminotransferase (AST), and direct bilirubin.

\section{Treatment and follow-up}

Postoperative follow-up data for all of the patients were obtained from the hospital database. RFS was calculated from the date of hepatectomy to the day of tumor recurrence. Follow-up time was calculated from the date of hepatectomy to January 2011 or death. Tumor recurrence was diagnosed using appropriate imaging modalities (such as computed tomography and magnetic resonance imaging) and blood tests (AFP levels). Patients with recurrence were offered appropriate therapeutic approaches, such as rehepatectomy and radiotherapy.

\section{Statistical analysis}

Data were analyzed using SPSS 23.0 (IBM Corp., Chicago, IL, USA). The median and quartile ranges were used to express continuous variables, and Mann-Whitney $U$ test was used to compare data between younger ( $\leq 40$ years old at study entry) and older ( $>40$ years old) patients. The percentages were used to express categorical variables and compared using the $x^{2}$ test. The Kaplan-Meier method was used to calculate the rate of survival and recurrence, and log-rank test was used for comparison. Differences were considered statistically significant when $p$ was $<0.05$. Independent risk factors for recurrence and OS were determined using univariate and multivariate logistic regression analyses.
According to the propensity score of clinicopathological characteristics, the whole sample was analyzed and matched with two groups of patients in a 1:1 ratio, with the caliper value of $0.1 .^{16,17}$ This matching procedure was used to reduce the influence of confounding factors.

\section{Results}

\section{Baseline clinicopathological characteristics}

The baseline clinicopathological characteristics of the patients are provided in Table 1 . A total of 465 younger patients $(\leq 40$ years) and 1567 older patients (>40 years) were included in the study. The younger patients showed significantly higher rates of hepatitis $B$ infection than older patients $(95.1 \%$ vs. $83.1 \%, p<0.001)$ as well as a significantly higher rate of elevated AFP, defined as $\geq 400 \mathrm{ng} / \mathrm{mL}(54.4 \%$ vs. $38.0 \%$, $p<0.001$ ). Preoperative liver function indices (ALB, PA, and platelet levels) were significantly better in younger patients $(p<0.05)$, who nevertheless showed worse BCLC stage; the frequencies of stage A-C were, respectively, $57.0 \%, 14.8 \%$, and $28.2 \%$ in the younger group compared to $65.3 \%, 16.5 \%$, and $18.1 \%$ in the older group. The rate of anatomical hepatectomy was higher in the younger group (32.3\% vs. $25.3 \%$, $p=0.003$ ). Postoperative pathology showed that younger patients generally had more advanced disease, including higher rates of vascular invasion $(27.1 \%$ vs. $17.7 \%$, $p<0.001$ ) and larger tumors (rate of tumors $>5 \mathrm{~cm}, 65.4 \%$ vs. $56.9 \%, p=0.001$ ).

There was no significant difference between the two groups in terms of other clinicopathological characteristics, including family history of HCC, sex, prevalence of cirrhosis, tumor number, hepatitis $C$ antibody, prothrombin time, AST levels, direct bilirubin levels, total bilirubin levels, incidence of postoperative ascites, tumor envelope integrity, or liver function grade.

Analysis of 451 propensity score-matched pairs of younger and older patients showed no significant differences in demographic or clinicopathological characteristics (Table 1).

\section{RFS and OS}

Median OS was 67 (range: 57.7-76.2) months in younger patients and 89 (76.9-101.0) months in older patients (Fig. 1). The median RFS of younger HCC patients was 12 (9.6-14.3) months, which was lower than that of older patients (17 (14.5-19.4) months). OS rates were $76.3 \%$ at 1 year, $60.1 \%$ at 3 years, and $50.9 \%$ at 5 years for younger patients, which were significantly lower than the corresponding rates of $83.5 \%, 65.9 \%$ and $57.9 \%$ for older patients. RFS rates were $47.7 \%, 25.9 \%$, and $20.8 \%$ for younger patients, which differed from the corresponding rates of $56.3 \%, 29.7 \%$ and $12.6 \%$ for older patients.

When we repeated these survival analyses using propensity score-matched pairs of younger and older patients, we observed no significant differences (Fig. 1).

\section{Predictors of RFS and OS}

Logistic regression was used to identify predictors of OS and RFS (Table 2). Univariate analysis showed that age $\leq 40$ years, male sex, vascular invasion, tumor number $>3$, tumor diameter $>5 \mathrm{~cm}$, serum platelet levels, serum PA level, serum ALB level, serum ALT level, serum AST level, 
Li C. et al: Age and HCC

Table 1. Clinicopathological data and prognosis of patients with HCC after undergoing hepatectomy

\begin{tabular}{|c|c|c|c|c|c|c|}
\hline \multirow[b]{2}{*}{ Variable } & \multicolumn{3}{|c|}{ Before propensity score matching } & \multicolumn{3}{|c|}{ After propensity score matching } \\
\hline & $\begin{array}{l}\text { Younger, } \\
n=465\end{array}$ & $\begin{array}{l}\text { Older, } \\
n=1567\end{array}$ & $p$ & $\begin{array}{l}\text { Younger, } \\
n=451\end{array}$ & Older, $n=451$ & $p$ \\
\hline Family history of HCC & $86(18.5 \%)$ & $246(15.7 \%)$ & 0.088 & $84(18.6 \%)$ & $76(16.9 \%)$ & 0.542 \\
\hline Male & $407(87.5 \%)$ & $\begin{array}{l}1340 \\
(85.5 \%)\end{array}$ & 0.288 & $394(87.4 \%)$ & $475(48.8 \%)$ & 0.091 \\
\hline Cirrhosis & $263(56.6 \%)$ & $896(57.2 \%)$ & 0.427 & $255(56.5 \%)$ & $244(54.1 \%)$ & 0.503 \\
\hline Vascular invasion & $126(27.1 \%)$ & $277(17.7 \%)$ & $<0.001$ & $118(26.2 \%)$ & $113(25.1 \%)$ & 0.703 \\
\hline Tumor number $>3 \mathrm{~cm}$ & $38(8.2 \%)$ & $98(6.3 \%)$ & 0.169 & $35(7.8 \%)$ & $34(7.5 \%)$ & 1.000 \\
\hline Tumor diameter $>5 \mathrm{~cm}$ & $304(65.4 \%)$ & $891(56.9 \%)$ & 0.001 & $290(64.3 \%)$ & $280(62.1 \%)$ & 0.534 \\
\hline $\begin{array}{l}\text { HBsAg-positive } \\
\text { Hepatitis C antibody } \\
\text { positivity }\end{array}$ & $\begin{array}{l}442(95.1 \%) \\
7(1.5 \%)\end{array}$ & $\begin{array}{l}1302 \\
(83.1 \%) \\
28(1.8 \%)\end{array}$ & $\begin{array}{l}<0.001 \\
0.682\end{array}$ & $\begin{array}{l}428(94.9 \%) \\
5(1.1 \%)\end{array}$ & $\begin{array}{l}421(93.3 \%) \\
7(0.5 \%)\end{array}$ & $\begin{array}{l}0.396 \\
0.162\end{array}$ \\
\hline Platelet count as $\times 10^{9} / \mathrm{L}$ & $208(163-263)$ & $\begin{array}{l}188(141- \\
245)\end{array}$ & $<0.001$ & $\begin{array}{l}207(162- \\
260)\end{array}$ & $\begin{array}{l}198.2(152.4- \\
257.0)\end{array}$ & 0.218 \\
\hline Prothrombin time in sec & $\begin{array}{l}12.9(12.0- \\
13.75)\end{array}$ & $\begin{array}{l}12.8(12.1- \\
13.7)\end{array}$ & 0.718 & $\begin{array}{l}12.9(12.0- \\
13.7)\end{array}$ & $12.7(11.9-13.5)$ & 0.068 \\
\hline Albumin in $\mathrm{g} / \mathrm{L}$ & $\begin{array}{l}41.9(39.4- \\
45.1)\end{array}$ & $\begin{array}{l}40.3(37.4- \\
43.4)\end{array}$ & $<0.001$ & $\begin{array}{l}41.7(39.2- \\
45.0)\end{array}$ & $42.1(38.6-44.8)$ & 0.692 \\
\hline Prealbumin in $\mathrm{g} / \mathrm{L}$ & $204(158-248)$ & $\begin{array}{l}190(145- \\
236)\end{array}$ & 0.002 & $\begin{array}{l}203(157- \\
247)\end{array}$ & $197(154-244)$ & 0.643 \\
\hline $\begin{array}{l}\text { Alanine aminotransferase in } \\
\mathrm{U} / \mathrm{L}\end{array}$ & $38(25-54)$ & $35(24-51)$ & 0.043 & $37(25-53)$ & $36(25-51)$ & 0.568 \\
\hline $\begin{array}{l}\text { Aspartate aminotransferase } \\
\text { in } U / L\end{array}$ & $39(29-58)$ & $39(29-57)$ & 0.774 & $39(29-58)$ & $40(30-62)$ & 0.111 \\
\hline Direct bilirubin in $\mu \mathrm{mol} / \mathrm{L}$ & $5(3.6-6.5)$ & $5(3.5-6.6)$ & 0.535 & $4.9(3.6-6.5)$ & $5.2(3.7-6.6)$ & 0.206 \\
\hline Postoperative ascites & $51(11.0 \%)$ & $228(14.6 \%)$ & 0.055 & $49(10.9 \%)$ & $62(13.7 \%)$ & 0.224 \\
\hline $\mathrm{AFP} \geq 400 \mathrm{ng} / \mathrm{mL}$ & $253(54.4 \%)$ & $596(38.0 \%)$ & $<0.001$ & $240(53.2 \%)$ & $239(53.0 \%)$ & 1.000 \\
\hline Incomplete tumor capsules & $182(39.1 \%)$ & $556(35.5 \%)$ & 0.154 & $178(39.5 \%)$ & $174(38.6 \%)$ & 0.838 \\
\hline Total bilirubin in $\mu \mathrm{mol} / \mathrm{L}$ & $\begin{array}{l}11.8(8.7- \\
15.7)\end{array}$ & $12.1(9-16.6)$ & 0.279 & $\begin{array}{l}11.8(8.6- \\
15.7)\end{array}$ & $12.3(8.8-16.3)$ & 0.272 \\
\hline Anatomical hepatectomy & $150(32.3 \%)$ & $396(25.3 \%)$ & 0.003 & $308(68.3 \%)$ & $309(68.5 \%)$ & 1.000 \\
\hline Portal hypertension & $100(21.5 \%)$ & $372(23.7 \%)$ & 0.318 & $98(21.7 \%)$ & $105(23.3 \%)$ & 0.632 \\
\hline Child-Pugh class & & & 0.716 & & & 0.382 \\
\hline$A$ & $444(95.5 \%)$ & $\begin{array}{l}1489 \\
(95.0 \%)\end{array}$ & & $431(95.6 \%)$ & $437(96.9 \%)$ & \\
\hline B & $21(4.5 \%)$ & $78(5.0 \%)$ & & $20(4.4 \%)$ & $14(3.1 \%)$ & \\
\hline BCLC stage & & & $<0.001$ & & & 0.552 \\
\hline 0/A & $265(57.0 \%)$ & $\begin{array}{l}1024 \\
(65.3 \%)\end{array}$ & & $261(57.9 \%)$ & $277(61.4 \%)$ & \\
\hline B & $69(14.8 \%)$ & $259(16.5 \%)$ & & $67(14.9 \%)$ & $62(13.7 \%)$ & \\
\hline $\mathrm{C}$ & $131(28.2 \%)$ & $284(18.1 \%)$ & & $123(27.3 \%)$ & $112(24.8 \%)$ & \\
\hline Disease-free survival & & & 0.040 & & & 0.382 \\
\hline 1-year & $222(47.7 \%)$ & $882(56.3 \%)$ & & $218(48.4 \%)$ & $241(53.6 \%)$ & \\
\hline 3-year & $120(25.9 \%)$ & $465(29.7 \%)$ & & $119(26.5 \%)$ & $154(34.3 \%)$ & \\
\hline 5-year & $96(20.8 \%)$ & $197(12.6 \%)$ & & $96(21.3 \%)$ & $82(18.2 \%)$ & \\
\hline Overall survival & & & 0.015 & & & 0.089 \\
\hline
\end{tabular}


Table 1. (continued)

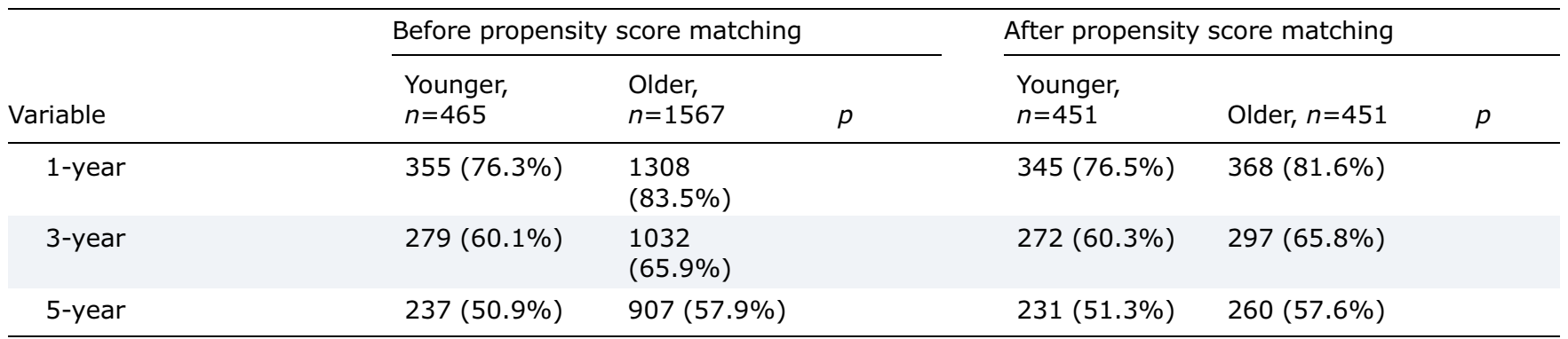

Values are $n(\%)$ or median (interquartile range), unless otherwise indicated.

Abbreviations: AFP, alpha-fetoprotein; BCLC, Barcelona Clinic Liver Cancer; HCC, hepatocellular carcinoma.
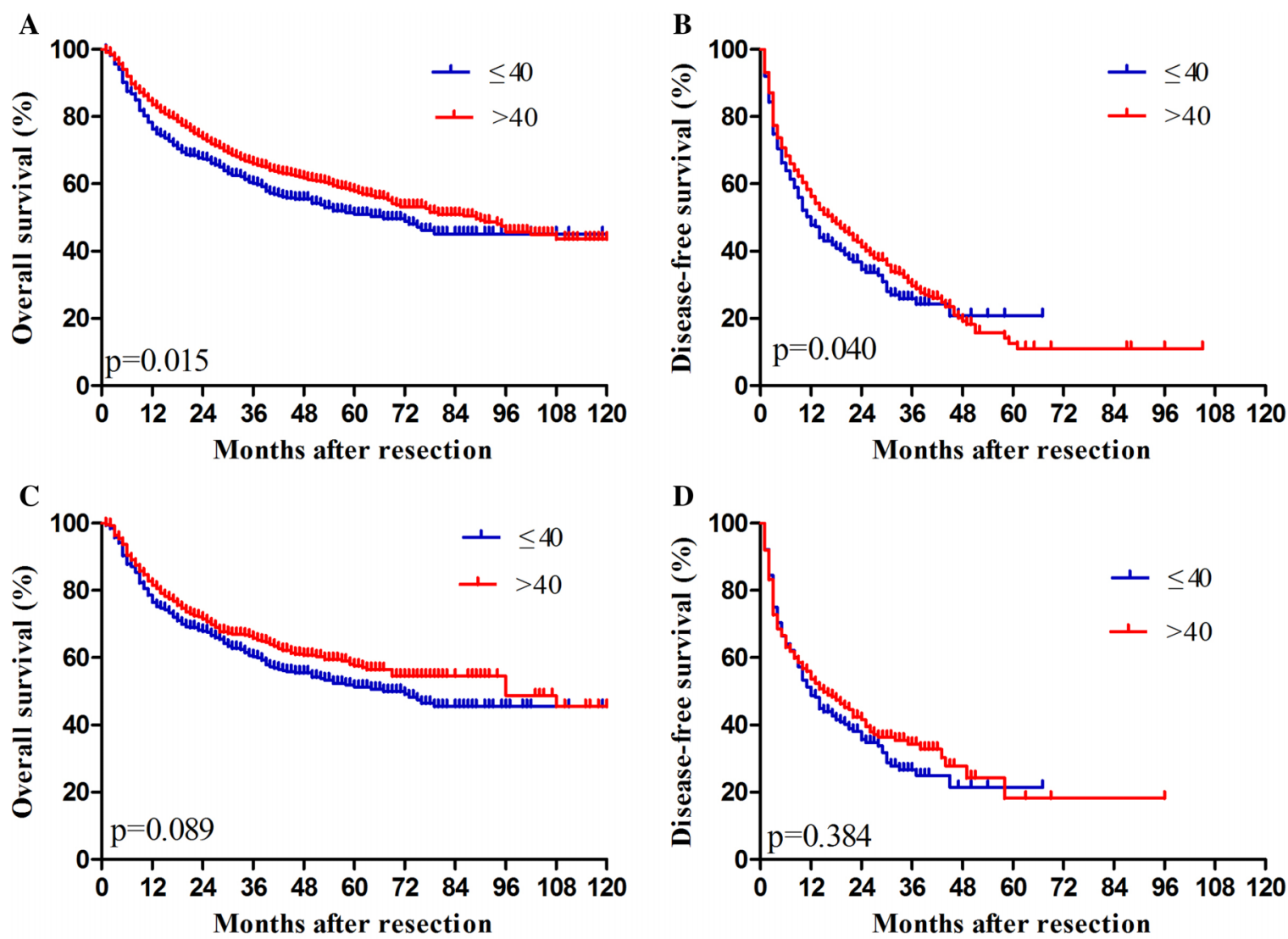

Fig. 1. Overall and disease-free survival rates of HCC patients after hepatectomy. (A, B) Before propensity score matching. (C, D) After propensity score matching.

AFP $\geq 400 \mathrm{ng} / \mathrm{mL}$, incomplete tumor capsule, anatomical hepatectomy, portal hypertension, and BCLC stage B or C were associated with poor OS. Multivariate analysis identified the following independent risk factors of poor OS: age $\leq 40$ years, male sex, vascular invasion, tumor number $>3$, tumor diameter $>5 \mathrm{~cm}$, decreased PA level, increased AST level, AFP $\geq 400 \mathrm{ng} /$ $\mathrm{mL}$, incomplete tumor capsule, and BCLC stage B or C.

Univariate analysis showed that the following factors were associated with RFS after hepatectomy: age $\leq 40$ years, vascular invasion, tumor number $>3$, tumor diameter $>5$ $\mathrm{cm}$, HBsAg-positive, serum PA levels, serum ALB levels, serum AST levels, AFP $\geq 400 \mathrm{ng} / \mathrm{mL}$, incomplete tumor capsule, anatomical hepatectomy, portal hypertension, and BCLC stage B or C. Subsequent multivariate analysis identified the following independent predictors of RFS: tumor diameter $>5 \mathrm{~cm}$, decreased PA level, incomplete tumor capsule, anatomical hepatectomy, portal hypertension, and $\mathrm{BCLC}$ stage $\mathrm{B}$ or $\mathrm{C}$.

\section{Discussion}

The clinicopathological data from 2032 HCC patients after hepatectomy was retrospectively analyzed in this study in order to gain an understanding about the effect of age on their 
Li C. et al: Age and HCC

Table 2. Univariate and multivariate analysis to identify prognostic factors in younger patients

\begin{tabular}{|c|c|c|c|c|c|c|c|c|}
\hline \multirow[b]{3}{*}{ Variable } & \multicolumn{4}{|c|}{ Disease-free survival } & \multicolumn{4}{|c|}{ Overall survival } \\
\hline & \multicolumn{2}{|c|}{ Univariate } & \multicolumn{2}{|c|}{ Multivariate } & \multicolumn{2}{|c|}{ Univariate } & \multicolumn{2}{|c|}{ Multivariate } \\
\hline & $p$ & $\begin{array}{l}\text { OR }(95 \% \\
\text { CI })\end{array}$ & $p$ & $\begin{array}{l}\text { OR }(95 \% \\
\text { CI })\end{array}$ & $p$ & $\begin{array}{l}\text { OR }(95 \% \\
\text { CI })\end{array}$ & $p$ & OR $(95 \% \mathrm{CI})$ \\
\hline $\begin{array}{l}\text { Age } \leq 40 \\
\text { years }\end{array}$ & 0.046 & $\begin{array}{l}1.116 \\
(1.003-1.358)\end{array}$ & 0.277 & $\begin{array}{l}1.091 \\
(0.931-1.278)\end{array}$ & 0.016 & $\begin{array}{l}1.219 \\
(1.038-1.432)\end{array}$ & 0.035 & $\begin{array}{c}1.199 \\
(1.013-1.418)\end{array}$ \\
\hline Male sex & 0.192 & $\begin{array}{l}1.140(0.936- \\
1.388)\end{array}$ & & & 0.039 & $\begin{array}{l}1.256(1.011- \\
1.560)\end{array}$ & 0.001 & $\begin{array}{c}1.162(0.553- \\
1.808)\end{array}$ \\
\hline $\begin{array}{l}\text { Vascular } \\
\text { invasion }\end{array}$ & $<0.001$ & $\begin{array}{l}2.277(1.957- \\
2.659)\end{array}$ & 0.781 & $\begin{array}{l}0.956(0.694- \\
1.315)\end{array}$ & 0.039 & $\begin{array}{l}0.796(0.641- \\
0.989)\end{array}$ & 0.045 & $\begin{array}{c}1.424(1.008- \\
2.012)\end{array}$ \\
\hline $\begin{array}{l}\text { Tumor } \\
\text { number }>3\end{array}$ & 0.015 & $\begin{array}{l}1.371(1.063- \\
1.768)\end{array}$ & 0.141 & $\begin{array}{l}0.815(0.621- \\
1.070)\end{array}$ & $<0.001$ & $\begin{array}{l}2.138(1.696- \\
2.694)\end{array}$ & 0.030 & $\begin{array}{c}1.325(1.028- \\
1.709)\end{array}$ \\
\hline $\begin{array}{l}\text { Tumor } \\
\text { diameter }>5 \\
\mathrm{~cm}\end{array}$ & $<0.001$ & $\begin{array}{l}1.562(1.363- \\
1.790)\end{array}$ & 0.024 & $\begin{array}{l}1.188(1.023- \\
1.381)\end{array}$ & $<0.001$ & $\begin{array}{l}2.283(1.958- \\
2.662)\end{array}$ & 0.000 & $\begin{array}{c}1.547(1.304- \\
1.836)\end{array}$ \\
\hline $\begin{array}{l}\text { HBsAg- } \\
\text { positive } \\
\text { Hepatitis C } \\
\text { antibody } \\
\text { positivity }\end{array}$ & $\begin{array}{l}0.026 \\
0.390\end{array}$ & $\begin{array}{l}1.259(1.028- \\
1.542) \\
1.005(0.995- \\
1.010)\end{array}$ & 0.103 & $\begin{array}{l}1.187(0.966- \\
1.459)\end{array}$ & $\begin{array}{l}0.064 \\
0.240\end{array}$ & $\begin{array}{l}1.220(0.988- \\
1.506) \\
1.007(0.994- \\
1.012)\end{array}$ & & \\
\hline $\begin{array}{l}\text { Platelet as } \\
\times 10^{9} / \mathrm{L}\end{array}$ & 0.097 & $\begin{array}{l}0.999(0.999- \\
1.000)\end{array}$ & & & 0.037 & $\begin{array}{l}0.999(0.998- \\
1.000)\end{array}$ & 0.447 & $\begin{array}{c}1.000(0.999- \\
1.001)\end{array}$ \\
\hline $\begin{array}{l}\text { Albumin in } \mathrm{g} / \\
\mathrm{L}\end{array}$ & 0.001 & $\begin{array}{l}0.975(0.962- \\
0.989)\end{array}$ & 0.785 & $\begin{array}{l}0.998(0.981- \\
1.015)\end{array}$ & $<0.001$ & $\begin{array}{l}0.949(0.936- \\
0.963)\end{array}$ & 0.089 & $\begin{array}{c}0.984(0.966- \\
1.002)\end{array}$ \\
\hline $\begin{array}{l}\text { Prealbumin } \\
\text { in } \mathrm{mg} / \mathrm{L}\end{array}$ & $<0.001$ & $\begin{array}{l}0.997(0.996- \\
0.998)\end{array}$ & 0.008 & $\begin{array}{l}0.998 \\
(0.997-1.000)\end{array}$ & $<0.001$ & $\begin{array}{l}0.995(0.994- \\
0.996)\end{array}$ & 0.000 & $\begin{array}{c}0.997(0.995- \\
0.995)\end{array}$ \\
\hline ALT in $U / L$ & 0.121 & $\begin{array}{l}1.001(1.000- \\
1.003)\end{array}$ & & & 0.008 & $\begin{array}{l}1.002(1.001- \\
1.003)\end{array}$ & 0.436 & $\begin{array}{c}0.999(0.997- \\
1.001)\end{array}$ \\
\hline AST in $U / L$ & $<0.001$ & $\begin{array}{l}1.003(1.002- \\
1.005)\end{array}$ & 0.098 & $\begin{array}{l}1.001(1.000- \\
1.003)\end{array}$ & $<0.001$ & $\begin{array}{l}1.005(1.004- \\
1.006)\end{array}$ & 0.001 & $\begin{array}{c}1.003(1.001- \\
1.005)\end{array}$ \\
\hline $\begin{array}{l}\text { AFP } \geq 400 \\
\mathrm{ng} / \mathrm{mL}\end{array}$ & $<0.001$ & $\begin{array}{l}1.291(1.132- \\
1.471)\end{array}$ & 0.130 & $\begin{array}{l}1.111(0.970- \\
1.273)\end{array}$ & $<0.001$ & $\begin{array}{l}1.471(1.280- \\
1.691)\end{array}$ & 0.025 & $\begin{array}{c}1.183(1.022- \\
1.369)\end{array}$ \\
\hline $\begin{array}{l}\text { Incomplete } \\
\text { tumor } \\
\text { capsule }\end{array}$ & $<0.001$ & $\begin{array}{l}1.551(1.357- \\
1.772)\end{array}$ & 0.002 & $\begin{array}{l}1.255(1.087- \\
1.448)\end{array}$ & $<0.001$ & $\begin{array}{l}1.872(1.629- \\
2.153)\end{array}$ & 0.000 & $\begin{array}{c}1.364(1.172- \\
1.586)\end{array}$ \\
\hline $\begin{array}{l}\text { Anatomical } \\
\text { hepatectomy }\end{array}$ & $<0.001$ & $\begin{array}{l}1.678(1.461- \\
1.927)\end{array}$ & 0.009 & $\begin{array}{l}1.228(1.053- \\
1.432)\end{array}$ & $<0.001$ & $\begin{array}{l}1.892(1.635- \\
2.190)\end{array}$ & 0.360 & $\begin{array}{c}1.081(0.915- \\
1.276)\end{array}$ \\
\hline $\begin{array}{l}\text { Portal } \\
\text { hypertension }\end{array}$ & 0.005 & $\begin{array}{l}1.237(1.067- \\
1.434)\end{array}$ & 0.037 & $\begin{array}{l}1.174(1.010- \\
1.364)\end{array}$ & 0.001 & $\begin{array}{l}1.310(1.120- \\
1.531)\end{array}$ & 0.052 & $\begin{array}{c}1.182(0.998- \\
1.400)\end{array}$ \\
\hline $\begin{array}{l}\text { BCLC stage } \\
\mathrm{B} / \mathrm{C}\end{array}$ & $<0.001$ & $\begin{array}{l}1.591(1.473- \\
1.719)\end{array}$ & $<0.001$ & $\begin{array}{l}1.436(1.212- \\
1.700)\end{array}$ & $<0.001$ & $\begin{array}{l}1.976(1.824- \\
2.140)\end{array}$ & 0.002 & $\begin{array}{c}1.345(1.115- \\
1.621)\end{array}$ \\
\hline
\end{tabular}

Abbreviations: AFP, alpha-fetoprotein; ALT, alanine aminotransferase; AST, aspartate aminotransferase; BCLC, Barcelona Clinic Liver Cancer; CI, confidence interval; OR, odds ratio.

prognosis. Although age boundaries are inconsistently defined in different literature, considering that the American guidelines for management of HCC recommend that Asian men older than 40 years be included in HCC screening, and in order to compare our results with those reported in most other studies, this study used age 40 as the age boundary. ${ }^{18}$ Our results show that younger HCC patients have larger tumors, more frequent vascular invasion, and more advanced tumors than older patients. In addition, younger HCC patients also had higher HBsAg-positive rates, better liver function, lower AFP levels, and higher rates of anatomical hepatectomy. Before propensity score matching, younger HCC patients had better RFS and OS than older patients but this difference disappeared after propensity score matching.

Although there have been many great studies showing that patients outside Milan criteria do not have a good treatment effect for hepatectomy, there are fewer patients who meet Milan criteria in China. According to the "Guidelines for Diagnosis and Treatment of Primary Liver Cancer in China" formulated according to China's national conditions and clinical practice, hepatectomy is recommended as the first treatment for patients with good liver function reserve or patients in stages Ia, Ib or IIa. This study was based on the 
Guidelines for Diagnosis and Treatment of Primary Liver Cancer in China. ${ }^{13}$

We found that younger HCC patients had more advanced tumors, although this may be an error in data collection; however, this does not seem to be accidental because similar results have been reported in most previous studies, so we have reason to believe that this may be a feature of the younger patient population itself. ${ }^{11,12,19-21}$ The reason underlying the more advanced stage of younger $\mathrm{HCC}$ tumors is still unclear, and may be related to gene expression differences. Previously, Ha et al. ${ }^{19}$ reported that there were significant differences in gene expression profiles between younger HCC patients and older HCC patients, and these abnormal genes were mainly related to cell cycle or cell mitosis, while the mitotic rate of HCC in younger patients was significantly higher than that in elderly patients, which indicated that the tumor aggressiveness of younger patients was stronger than that of older patients. This further confirmed our results.

Previous studies have indicated that younger patients with HCC often have more serious disease than older patients and that the greater prevalence of large tumors and vascular invasion in these patients leads to a higher rate of anatomical hepatectomy. ${ }^{11,22}$ Consistent with this, we found that the younger HCC patients in our sample had higher rates of hepatitis B infection, advanced tumors, elevated AFP, and anatomical hepatectomy. The reason why the HBsAg-positive rate of younger patients is higher than that of older patients may be related to the negative correlation between the quantitative value of $\mathrm{HBsAg}$ and age. ${ }^{23}$

Although the proportion of non-cirrhotic patients in both groups was nearly half, more than $95 \%$ of patients in each group had liver function classified as Child-Pugh $\mathrm{A}$. This ratio seems too high. However, since the diagnosis of cirrhosis in this study was based on reference to preoperative imaging findings, these results cannot lead to conclusions about the potential link between cirrhosis and the liver. ${ }^{24}$ More research is needed to further prove this potential link. The interesting point in this study is the fact that younger patients, despite the absence of cirrhosis (44\%), had more advanced HCC. In theory, the progression from cirrhosis to HCC takes a long period of time. Younger HCC patients seem to experience this process for a shorter time; however, the tumors are more advanced in younger than older patients, which may be related to the biological characteristics of the tumors. Since, in our study, tumor grading was not reported in the pathological reports of most patients, more studies are needed in the future to prove this.

Although previous work has suggested that the more advanced $\mathrm{HCC}$ in younger patients translates to worse prognosis, studies have given divergent answers to the question of whether younger patients have worse or better prognosis than older patients. We found that the prognosis of young patients was worse than that of older patients but this was not the case after propensity score matching. ${ }^{22,25,26}$ The discrepancies in previous studies may reflect differences in ethnicity, cut-off age for defining "younger" and "older", and clinicopathological differences before surgery. We used propensity score matching to reduce potential confounding from baseline differences, allowing us to isolate the effects of age. Our findings are consistent with a retrospective study of 1132 Chinese patients with HCC who underwent hepatectomy. Stratifying these patients by various cut-off ages between 30 and 70 years showed that age did not significantly affect their prognosis. ${ }^{27}$ We obtained similar results when we applied cut-off ages of 30 and 50 years (data not shown).

Instead of age, our regression analyses identified several variables that predict post-hepatectomy survival, including serum AFP levels, vascular invasion, and tumor diameter. These variables have previously been associated with postoperative survival of HCC patients in numerous countries. ${ }^{28-30}$ The fact that age by itself does not appear to affect survival is interesting, given the often much more severe disease that they suffered compared to older patients, including higher rates of vascular invasion, larger and more aggressive tumors.

One of the limitations of our study is its retrospective nature, which limited the data that we could analyze. This, in turn, may have biased our propensity score matching procedure. Our study focused solely on patients who underwent hepatectomies, so whether our findings apply to patients with unresectable HCC remains to be seen.

Despite these limitations, our study provides evidence that age per se does not affect the prognosis of HCC patients. Our results also suggest the need to expand the indications for HCC screening to young Asians diagnosed with chronic hepatitis $B$ virus infection.

\section{Conclusions}

Age did not appear to affect postoperative prognosis for HCC. Younger patients showed different clinicopathological characteristics than older patients, such as higher rates of hepatitis $B$ infection and advanced tumors. We recommend that young Asians diagnosed with hepatitis B infection be included in HCC screening and surveillance programs.

\section{Funding}

This work was partly supported by the Self-Raised Scientific Research Fund of the Ministry of Health of Guangxi Province (Z2016512, Z2015621, Z20200923), the Graduate Course Construction Project of Guangxi Medical University (YJSA2017014), the Guangxi Natural Science Foundation (2018GXNSFBA138018 and 2020GXNSFAA159022), the National Major Special Science and Technology Project (2017ZX10203207), and the 'Guangxi BaGui Scholars' Special Fund.

\section{Conflict of interest}

The authors have no conflict of interests related to this publication.

\section{Author contributions}

Drafting manuscript $(\mathrm{CL}, \mathrm{JHZ})$, statistical analysis $(\mathrm{KC})$, data collection (XL, HTL, XML, GLL, STT, RRH, LM, BDX), and revision of the manuscript for important intellectual content $(\mathrm{JHZ})$.

\section{References}

[1] Bray F, Ferlay J, Soerjomataram I, Siegel RL, Torre LA, Jemal A. Global cancer statistics 2018: GLOBOCAN estimates of incidence and mortality worldwide for 36 cancers in 185 countries. CA Cancer J Clin 2018;68:394-424. doi: 10 3322/caac. 21492.

[2] Zhong JH, Ke Y, Gong WF, Xiang BD, Ma L, Ye XP, et al. Hepatic resection associated with good survival for selected patients with intermediate and 
advanced-stage hepatocellular carcinoma. Ann Surg 2014;260:329-340. doi: 10.1097/SLA.0000000000000236.

[3] Zhong JH, Peng NF, You XM, Ma L, Xiang X, Wang YY, et al. Tumor stage and primary treatment of hepatocellular carcinoma at a large tertiary hospital in China: A real-world study. Oncotarget 2017;8:18296-18302. doi: 10. 18632/oncotarget.15433.

[4] Zhong JH, Pan LH, Wang YY, Cucchetti A, Yang T, You XM, et al. Optimizing stage of single large hepatocellular carcinoma: A study with subgroup analysis by tumor diameter. Medicine (Baltimore) 2017;96:e6608. doi: 10. 1097/MD.0000000000006608.

[5] Tsilimigras DI, Bagante F, Sahara K, Moris D, Hyer JM, Wu L, et al. Prognosis after resection of barcelona clinic liver cancer (BCLC) stage $0, a$, and $b$ hepatocellular carcinoma: A comprehensive assessment of the current BCLC classification. Ann Surg Oncol 2019;26:3693-3700. doi: 10.1245/s10434019-07580-9.

[6] Shuqun C, Mengchao W, Han C, Feng S, Jiahe Y, Guanghui D, et al. Tumor thrombus types influence the prognosis of hepatocellular carcinoma with the tumor thrombi in the portal vein. Hepatogastroenterology 2007;54:499502.

[7] Wan J, Grossman HB. Bladder carcinoma in patients age 40 years or younger. Cancer 1989;64:178-181. doi: 10.1002/1097-0142(19890701)64:1.

[8] Shaha AR, Shah JP, Loree TR. Risk group stratification and prognostic factors in papillary carcinoma of thyroid. Ann Surg Oncol 1996;3:534-538. doi: 10. 1007/BF02306085.

[9] Adami HO, Malker B, Holmberg L, Persson I, Stone B. The relation between survival and age at diagnosis in breast cancer. N Engl J Med 1986;315:559563. doi: 10.1056/NEJM198608283150906.

[10] Theuer CP, Kurosaki T, Taylor TH, Anton-Culver H. Unique features of gastric carcinoma in the young: a population-based analysis. Cancer 1998;83:2533. doi: 10.1002/(SICI)1097-0142(19980701)83:1.

[11] Chang PE, Ong WC, Lui HF, Tan CK. Is the prognosis of young patients with hepatocellular carcinoma poorer than the prognosis of older patients? A comparative analysis of clinical characteristics, prognostic features, and survival outcome. J Gastroenterol 2008;43:881-888. doi: 10.1007/s00535-0082238-x.

[12] Kim JH, Choi MS, Lee H, Kim DY, Lee JH, Koh KC, Yoo BC, Paik SW, Rhee JC. Clinical features and prognosis of hepatocellular carcinoma in young patients from a hepatitis B-endemic area. J Gastroenterol Hepatol 2006;21:588-594. doi: 10.1111/j.1440-1746.2005.04127.x.

[13] Zhou J, Sun HC, Wang Z, Cong WM, Wang JH, Zeng MS, et al. Guidelines for diagnosis and treatment of primary liver cancer in China (2017 Edition). Liver Cancer 2018;7:235-260. doi: 10.1159/000488035.

[14] Zhong JH, Xiang BD, Gong WF, Ke Y, Mo QG, Ma L, et al. Comparison of longterm survival of patients with BCLC stage B hepatocellular carcinoma after liver resection or transarterial chemoembolization. PLoS One 2013;8: e68193. doi: 10.1371/journal.pone.0068193.

[15] EASL Clinical Practice Guidelines: Management of hepatocellular carcinoma. J. Hepatol 2018;69:182-236. doi: 10.1016/j.jhep.2018.03.019.

[16] McCaffrey DF, Griffin BA, Almirall D, Slaughter ME, Ramchand R, Burgette LF. A tutorial on propensity score estimation for multiple treatments using generalized boosted models. Stat Med 2013;32:3388-3414. doi: 10 . 1002/sim.5753.

[17] Austin PC. A comparison of 12 algorithms for matching on the propensity score. Stat Med 2014;33:1057-1069. doi: 10.1002/sim.6004.

[18] Bruix J, Sherman M. Management of hepatocellular carcinoma. Hepatology 2005;42:1208-1236. doi: 10.1002/hep.20933.

[19] Ha SY, Sohn I, Hwang SH, Yang JW, Park CK. The prognosis of hepatocellular carcinoma after curative hepatectomy in young patients. Oncotarget 2015; 6:18664-18673. doi: 10.18632/oncotarget.4330.

[20] Su CW, Lei HJ, Chau GY, Hung HH, Wu JC, Hsia CY, et al. The effect of age on the long-term prognosis of patients with hepatocellular carcinoma after resection surgery: a propensity score matching analysis. Arch Surg 2012; 147:137-144. doi: 10.1001/archsurg.2011.288.

[21] Furuta T, Kanematsu T, Matsumata T, Shirabe K, Yamagata M, Utsunomiya T, et al. Clinicopathologic features of hepatocellular carcinoma in young patients. Cancer 1990;66:2395-2398. doi: 10.1002/1097-0142 (19901201)66:11.

[22] Takeishi K, Shirabe K, Muto J, Toshima T, Taketomi A, Maehara Y. Clinicopathological features and outcomes of young patients with hepatocellular carcinoma after hepatectomy. World J Surg 2011;35:1063-1071. doi: 10. 1007/s00268-011-1017-7.

[23] Chen YC, Jeng WJ, Chu CM, Liaw YF. Decreasing levels of HBsAg predict HBsAg seroclearance in patients with inactive chronic hepatitis B virus infection. Clin Gastroenterol Hepatol 2012;10:297-302. doi: 10.1016/j.cgh. 2011.08.029.

[24] Ito K, Mitchell DG. Imaging diagnosis of cirrhosis and chronic hepatitis. Intervirology 2004;47:134-143. doi: 10.1159/000078465.

[25] Niederle IM, Wörns MA, Koch S, Nguyen-Tat M, Düber C, Otto G, et al. Clinicopathologic features and prognosis of young patients with hepatocellular carcinoma in a large German cohort. J Clin Gastroenterol 2012;46:775-778. doi: $10.1097 /$ MCG.0b013e31826102cc.

[26] Cho SJ, Yoon JH, Hwang SS, Lee HS. Do young hepatocellular carcinoma patients with relatively good liver function have poorer outcomes than elderly patients? J Gastroenterol Hepatol 2007;22:1226-1231. doi: 10. 1111/j.1440-1746.2007.04914.x.

[27] Tan JT, Zhao C, Peng NF, Yang Y, Zhong JH, Yang T, et al. Association between age and overall survival of patients with hepatocellular carcinoma after hepatic resection. J Surg Oncol 2016;114:966-970. doi: 10.1002/jso. 24434.

[28] Lurje G, Bednarsch J, Czigany Z, Amygdalos I, Meister F, Schöning W, et al. Prognostic factors of disease-free and overall survival in patients with hepatocellular carcinoma undergoing partial hepatectomy in curative intent. Langenbecks Arch Surg 2018;403:851-861. doi: 10.1007/s00423-0181715-9.

[29] Wakayama K, Kamiyama T, Yokoo H, Orimo T, Shimada S, Einama T, et al. Huge hepatocellular carcinoma greater than $10 \mathrm{~cm}$ in diameter worsens prognosis by causing distant recurrence after curative resection. J Surg Oncol 2017;115:324-329. doi: 10.1002/jso.24501.

[30] Silva JP, Gorman RA, Berger NG, Tsai S, Christians KK, Clarke CN, et al. The prognostic utility of baseline alpha-fetoprotein for hepatocellular carcinoma patients. J Surg Oncol 2017;116:831-840. doi: 10.1002/jso.24742. 